\title{
An analysis of the relationship between work engagement, work locus of control, passion, and parasitism in coastal hotels
}

\author{
Selcen Seda Turksoy ${ }^{1 *}$ and Ozkan Tutuncu ${ }^{2}$
}

\footnotetext{
${ }^{1}$ Cesme Faculty of Tourism, Ege University, Cesme-İzmir, Turkey. E-mail: selcen.seda.turksoy@ege.edu.tr

2 Dokuz Eylul University, Sport Sciences Faculty, Dokuz Eylul University, Izmir, Turkey

* Corresponding author
}

\begin{abstract}
The study explores the relationships among work engagement, work locus of control, passion, and perceived parasitism through the job demands-resources model (JD-R). Data were collected from five-star hotel employees in Cesme, Turkey using a structured questionnaire while the research hypotheses were tested by structural equation modelling. The results revealed that hospitality business employees' perceived community-directed parasitic relations decreased their work engagement while leading them to have an external work locus of control. In contrast, employees with internal work locus of control felt harmonious passion for their work, which increased work engagement. In addition, internal work locus of control led to harmonious and obsessive passion whereas external work locus of control led to obsessive passion. Regarding engagement, parasitic relations can be prevented, and harmonious passion can be created through the fair behaviours of managers, good assignment by the authorities, and the responsibility of employees. This requires feedback and performance monitoring processes based on objective criteria. Increasing the number of engaged employees which in turn improves business performance may also help reduce workforce turnover, which is a significant issue for hospitality businesses.
\end{abstract}

Keywords: Work Engagement, Work Locus of Control, Passion, Parasites in Organizations, Hospitality, Structural Equation Modeling

Citation: Turksoy, S.S. and Tutuncu, O. (2021). An analysis of the relationship between work engagement, work locus of control, passion, and parasitism in coastal hotels. European Journal of Tourism Research 29, 2912. 


\section{Introduction}

Today, hotels are supposed to increase the number of repeat guests, improve customer loyalty and maximize their profit in a high competitive environment of hospitality and service industry. By doing that providing high-quality services in line with customer demands and expectations has become a key issue. However, the characteristic feature of the tourism product or service itself may create significant differences in delivery, standardization and quality control, and customer satisfaction (Kozak, Kozak, \& Kozak, 2015). Therefore, hotels need to focus on employees in order to increase the perceived quality of the services. One of the most important ways to keep customer satisfaction high may be increasing employee work engagement because in front of service employees are the first to deal with the customers' ever-changing (and increasing) preferences, demands, and expectations of labour-intensive hospitality businesses. Schaufeli, Salanova, Gonzalez-Roma, and Bakker (2002) defined engagement as a positive, fulfilling psychological state that deeply affects employees' job performance providing several organizational benefits. More specifically, it improves employee performance (Arakawa \& Greenberg, 2007; Bakker \& Bal, 2010; Bakker, Van Emmerik, \& Euwema, 2006; Rich, Lepine, \& Crawford, 2010), job satisfaction (Lee, 2012), emotional organizational commitment (Schaufeli \& Bakker, 2004), extra role behaviour and organizational citizenship behaviour (Kang, 2014), productivity (Attridge, 2009), and profitability (Xanthopoulou, Bakker, Demerouti, \& Schaufeli, 2009), service recovery and creative performance (Karatepe, 2012). Engaged employees are more energetic, have more positive emotions, and provide positive self-feedback by managing their own resources (Bakker, 2009). This positive process improves the performance of both the engaged individual and other employees. Such employees can improve team performance by spreading their engagement through collaborative effort (Bakker, Demerouti, \& Xanthopoulou, 2012).

However; it is not always possible to work with engaged employees. The inter-individual competitionbased working culture constantly pushes employees to compete with each other, which causes individuals not only to fulfil the responsibilities required by their jobs, but also show non-ethical behaviours in accordance with the change of balance of power in institutional and socio-cultural structure in Turkey (Ozbilgin, Kucukaltan, \& Acar, 2019). They may perform parasitic relations in the organizations in order to get promoted and obtain privileges as well as economic benefits such as reward, being favoured (Atalay \& Acar, 2016). Parasitic relations may easily make organizations unhealthy and inefficient and decrease the level of engagement. A parasite is generally defined as a person who exploits the hospitality of the rich and earns their welcome by flattery (Merriam Webster, 2016). An organizational parasite is someone who receives support, advantage, or any other benefit as a result of organizational policies while providing no return (Hicks \& Gullet, 1981). In the literature, parasitic relations are variously described as free riding, individual selfishness, and putting individual interests over collective interests. Behaviours like favouritism between employees, shifting responsibility onto another, and merely appearing to be working, are difficult for other employees to bear. Such behaviour may damage motivation, reduce trust, provoke negative emotions, increase perceived inequality (Felps, Mitchell, \& Byington, 2006) and defensive responses. These destructive outcomes can easily change the way how co-workers think. The co-workers can easily believe they have no control over their career development path and reduce their motivation. Regulating one's own control and motivation becomes hard for such employees. However, work locus of control which explains whether individuals have internal or external motivation has an important role in the engagement process of the employees. The former tend to be more engaged in work by reducing job demands and managing their job resources well. They also have stronger job resources, which can reduce the negative effects of work demand (Jha \& Nair, 2008). Conversely, people with external locus of control cannot manage the pressures and uncertainties that challenge them at work (Rahim \& 
Psenicka, 1996). Thus, it is important for hospitality businesses to find ways to motivate such employees and then create work engagement.

Passion may be another phenomenon parasitism at work can affect. Employees can create an uncontrollable activity engagement (obsessive passion) because of certain contingencies are attached to the work (such as success, acceptance etc.). This situation can damage the person's relationship with other individuals and can lead to negative outcomes (Vallerand, 2010). In the study of Houlfort, Vallerand, Lavigne, Koesnter, Forest, Benabou., \& Crevier-Brauod. (2011), they found that obsessive passion reduces the positive emotions of employees which are very important for the engagement process.

Investigated as a job demand organizational parasitism with these possible related outcomes is thus an important problem for organizations that needs to be detected to enable efficient use of human resources. However, previous studies have failed to discuss the effect of perceived parasitic relationships at work on engagement, work locus of control and passion. The hotels should find ways to gain benefits of employee, team and organizational positive outcomes of engagement because the presence of highly satisfied and highly motivated employees enables the company to develop sustainable competitive advantages that can decisively improve its performance (Jiang, Lepak, Hu, \& Baer, 2012). Hospitality businesses must therefore start by recruiting the right employees before providing and maintaining a work environment that encourages increased engagement (Karatepe \& Olugbade, 2016).

The conceptual framework for the present study is based on the job demands-resources (JD-R) model proposed by Schaufeli (2013). Therefore, the theoretical issue for this study aims to find out in particular whether perceived parasitism affects work engagement, work locus of control, and passion. It explores if there are theoretical differences in hotel settings in Turkey based on other related variables, including work locus of control, passion. The results can benefit employees, management, and ultimately the overall performance of hospitality enterprises.

\section{Literature review}

The job demand-resources (JD-R) model as theoretical framework

The relationships between the variables are explained through the JD-R model. JD-R theory is one of the widely-used theories to explain the antecedents of employee engagement (Bakker, Demerouti, \& Sanz-Vergel, 2014). This model refers to two different psychological processes: employee motivation and health impairment (Demerouti, Bakker, De Jonge, \& Janssen, 2001). According to the JD-R model, work engagement stems from the inherently motivating nature of resources; job and personal resources (Schaufeli, 2013). Job resources are the positive physical, social, or organizational aspects that can help employees meet job targets, decrease job demands, or encourage personal development (Schaufeli \& Taris, 2014). Job resources, such as social support of colleagues and managers, feedback on performance, autonomy, and diversity of skills, start a motivational process that enables work engagement and high performance. Personal resources refer to employee beliefs about their control of the work environment (Schaufeli, 2013). Because they require constant physical and psychological effort, job demands are associated with physiological and psychological costs, and with the negative physical, social, and organizational aspects of the job. As job demands increase (excessive workload, emotional and mental requirements, etc.) so do the job resources required to maintain work engagement. This is where the importance of job resources is clear. Both personal resources and job resources together and personal resources alone affect work engagement (Bakker \& Demerouti, 20o8). There is also a cross link between the processes of motivation and health impairment. Weakness in job resources can also lead to exhaustion, while job demands can increase engagement to work. Consistent with the theory, 
employees' work locus of control and work passion may be intrinsic or extrinsic motivators (personal job resources) for the engagement process while perceived parasitic relationships (job demand) may be a stressor which is hard to deal with. Therefore, the study has its theoretical roots in the JD-R model, which assumes relationship between work locus of control, passion, parasitism and employee engagement.

\section{Work Locus of Control - Work Engagement}

By increasing personal resources, personality traits can provide job resources (Xanthopoulou et al., 2009). Personal resources and job resources can both ameliorate the health impairing effects of job demands (Mäkikangas \& Kinnunen, 2003). Employees with an internal work locus of control may be engaged more by reducing job demands and managing job resources well. People with internal work locus of control have stronger job resources, which may reduce the negative effects of job demands (Jha \& Nair, 2008). Internal locus of control, social support, and work autonomy can all offset the negative effects of stressors on well-being (Daniels \& Guppy, 1994). For example, Koeske and Kirk (1995) found an inverse relationship between internal locus of control and emotional exhaustion in mental health professionals while Etzion and Westman (1994) reported sense of control is inversely related to burnout in military personnel). Similarly, individuals with external locus of control may experience burnout syndrome (De Hoogh \& Hartog, 2009).

Rahim and Psenicka (1996) revealed that people with external locus of control cannot manage pressures and ambiguities that challenge them at work. Lee (2012) considered work locus of control as the fourth component of a theory of self-concept along with self-esteem, generalized self-efficacy, and emotional stability. Sense of control, along with the other dimensions, affected work engagement. Manzano, Montanes, and Megias (2017) investigated how nurses' perceptions of economic crisis affected burnout and engagement. They also examined the mediation effect of socio-demographic variables (age and sex) and personal control factors (self-efficacy, locus of control, and success). External locus of control was positively predicted burnout. These studies thus suggest that there is a relationship between work locus of control and work engagement, as in the model developed for this study. This leads to the following hypotheses:

\section{$H_{1}$ : Internal work locus of control increases employees' work engagement. \\ $H_{2}$ : External work locus of control decreases employees' work engagement.}

\section{Passion - Work Engagement}

In the literature, passion is addressed in two different dimensions: harmonious passion and obsessive passion, depending on the individual's self-identity and how they internalize the activity (Vallerand, et al., 2003). Individuals with a harmonious passion at work gain positive experiences by being more flexible, more responsible in their professional jobs. People with obsessive passion often experience anger, frustration, and conflicts over other areas of life when not engaged in their professional work. The obsessive passion prevents investment in other areas of life and precludes the opportunity for one's cognitive, behavioural enrichment and revival (Houlfort, Fernet, Vallerand, Laframboise, Guay, \& Koestner, 2015). Considering that job resources facilitate the achievement of work goals and promote personal development (Bakker \& Demerouti, 2008) the job will be internalized autonomously. This suggests that job resources may reduce obsessive passion while promoting harmonious passion. Conversely, job demands may reduce harmonious passion while promoting obsessive passion. Finally, due to the pressures created by job demands, employees may feel forced to work intensively, which may encourage a more controlled internalization of work. 
Previous studies have examined the relationship of job demands and resources to harmonious passion and obsessive passion. Job demands are positively correlated with obsessive passion and negatively correlated with harmonious passion whereas job resources are negatively correlated with obsessive passion and positively correlated with harmonious passion (Trépanier, Fernet, Austin, Forest, \& Vallerand, 2014). Job resources may also increase work engagement through the mediation effect of harmonious passion (Trépanier et al., 2014). Harmonious passion is also negatively correlated with the three dimensions of burnout whereas obsessive passion is positively correlated with emotional exhaustion and depersonalization (Fernet, Lavigne, Vallerand, \& Austin, 2014). Given these findings, we can propose the following hypotheses:

$\mathrm{H}_{3}$ : Harmonious passion increases work engagement.

$\mathrm{H}_{4}$ : Obsessive passion decreases work engagement.

\section{Perceived Parasitism - Work Engagement}

Job demands function as stressors and may require constant physical or psychological effort. These demands can include negative physical, social, and organizational conditions (Schaufeli \& Taris, 2014). Job resources may also be perceived as job demands if employees see job resources as a threat instead of an opportunity to learn and grow. Although team harmony, cohesion and good relations between employees are important job resources affecting work engagement (Schaufeli \& Taris, 2014; Anitha, 2014) they may also be perceived negatively as a threat instead of an opportunity for employee development and growth, thereby adding an extra psychological and physiological burden. In today's organizations, parasitism can be defined as benefiting from the productivity of other employees by staying within the organization in various ways, even though their skills and competencies do not exactly match the position they work in. Employees' lack of helpful coaching and adequate feedback from co-workers in a team may try hard to create their resources for professional development and get motivated and engaged. The perceived parasitic relations may result in lack of effort and motivation loss. This study therefore considers parasitism in the context of negative relations in the business environment as a job demand, leading to the following hypotheses.

$H_{5}$ : There is a relationship between perceived community-directed parasitism and work engagement.

$H_{6}$ : There is a relationship between perceived self-directed parasitism and work engagement.

\section{Work locus of Control - Passion}

Harmonious passion enables an individual to fully participate in the passionate activity through mental attention, concentration, and workflow due to integrative internal processes. In contrast, obsessive passion replaces integrative internal processes with ego whereby the individual focuses on their work while focusing on external elements like output and other employees (Vallerand, Houlfort, \& Forest, 2014: 90). Moreover, if the individual has a controlled personality (someone who usually fulfills responsibilities due to internal or external pressure), controlled internalization occurs and this leads to obsessive passion (Vallerand et al., 2014: 97). Therefore, there is a correlation between external locus of control and obsessive passion. Zigarmi, Galloway and Robert, (2018), for example, showed that internal and external locus of control have specific weak and moderate correlations with two-dimensional passion, and internal locus of control increases harmonious passion whereas external locus of control increases obsessive passion. This suggests the following four hypotheses:

$H_{7 a}$ : Internal work locus of control increases harmonious passion.

$H_{7 b}$ : Internal work locus of control decreases obsessive passion.

$H_{8 a}$ : External locus of control increases obsessive passion. 
$H_{8 b}$ : External locus of control decreases harmonious passion.

\section{Parasitism, Passion, and Work Locus of Control}

Job resources and personal resources together or personal resources only, affect work engagement. Individuals with high optimism, self-efficacy, resilience, and self-respect may become more engaged by managing job resources better (Bakker \& Demerouti, 2008). Employees with high job resources may also maintain work engagement by successfully managing their relations with other employees. The engaged employees with internal locus of control and harmonious passion may not be affected by the perceived parasitism because they can have higher resources to manage their abilities and to achieve their goals with motivation. On the other hand, employees with external locus of control may get disappointed by the presence of parasites and feel that whatever they do being promoted, getting overpay etc. are not as a result of individual success or effort. They may also get obsessed with the job which in turns exhaustion later. This leads to the following nine hypotheses:

$H_{9}$ : There is a relationship between perceived self-directed parasitism and obsessive passion.

$H_{10}$ : There is a relationship between perceived community-directed parasitism and obsessive passion.

$H_{11}$ : There is a relationship between self-directed parasitism and external work locus of control.

$H_{12}$ : There is a relationship between perceived community-directed parasitism and external work locus of control.

$H_{13}$ : External work locus of control mediates the relationship between perceived community-directed parasitism and work engagement.

$H_{14}$ : External locus of control mediates the relationship between self-directed parasitism and work engagement.

$H_{15}$ : Obsessive passion mediates the relationship between community-directed parasitism and work engagement.

$H_{16}$ : Obsessive passion mediates the relationship between self-directed parasitism and work engagement. $H_{17}$ : Harmonious passion mediates the relationship between internal locus of control and work engagement.

Figure 1 shows all the relationships between the study variables and their respective hypotheses.

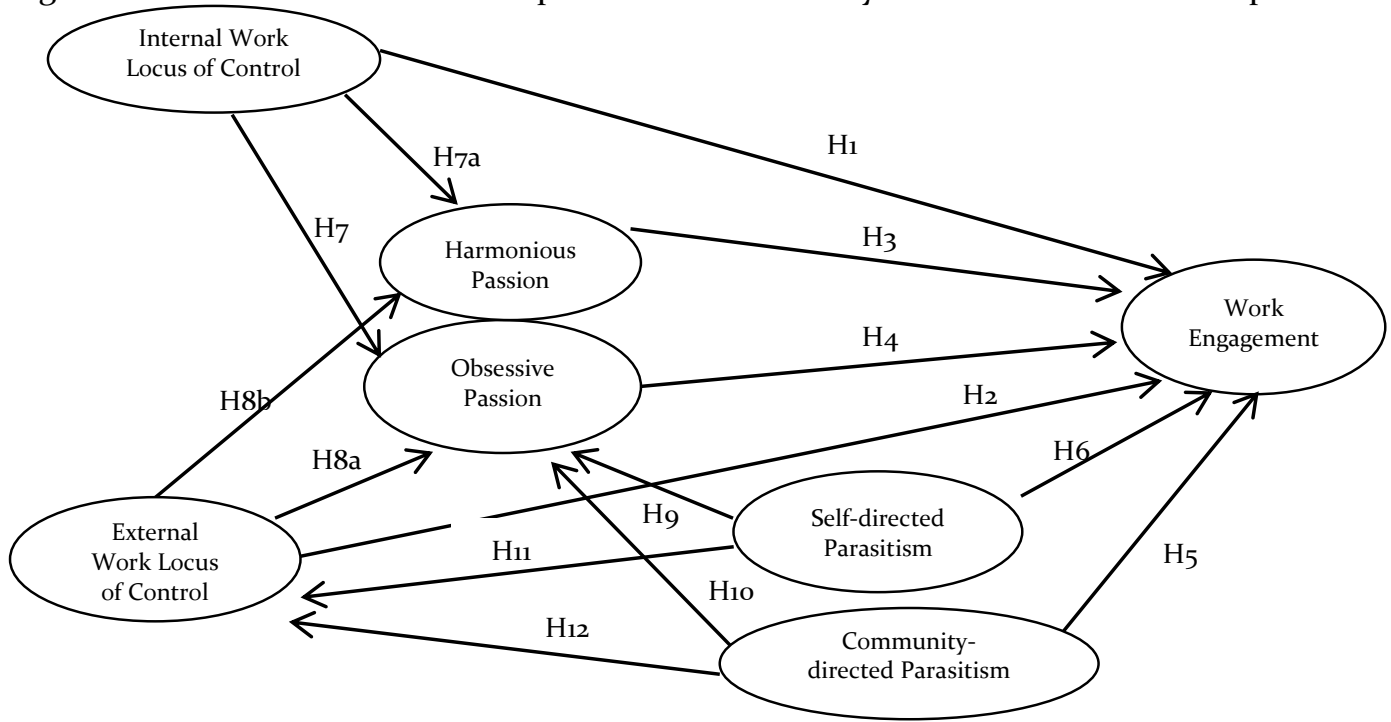

Figure 1. Hypothesized Model. 


\section{Methods}

Respondents and data collection

To test the hypotheses, five-star hotel employees in the Cesme district of Izmir province, Turkey, were chosen from the district's five five-star hotels (Izmir Directorate of Culture and Tourism, 2017). A total of 480 employees were found to be working at five hotels. A structured questionnaire was developed within the framework of literature, piloted, and revised. Face-to-face and pick-up techniques were used for data collection. The data were collected by a convenience sampling method. Great care was taken to find willing personnel to fill out the questionnaires which were distributed to all personnel working in the different units of each hotel. After eliminating 32 invalid questionnaires due to missing responses, 241 completed questionnaires were included in the study, which is sufficient for Hair, Black, Babin, and Anderson (2014). The respondents consisted of $41.9 \%$ females and $57.7 \%$ males while employees with undergraduate degree were the largest group of respondents at $52.7 \%$, followed by high school graduates with $3.7 \%$. Thus, the education level of the respondent employees was high. Respondents mainly worked in non-managerial positions (74.3\%), full time (91.7\%), and mainly in food and beverage, front desk, and housekeeping services (Table 1).

Table 1. Demographics

\begin{tabular}{|c|c|c|c|c|c|c|c|}
\hline & & $\begin{array}{l}\text { Number } \\
(\mathrm{N})\end{array}$ & $\begin{array}{l}\text { Percent } \\
(\%)\end{array}$ & & & $\begin{array}{l}\text { Number } \\
(\mathrm{N})\end{array}$ & $\begin{array}{l}\text { Percent } \\
(\%)\end{array}$ \\
\hline \multirow[t]{6}{*}{ Sex } & Female & 101 & 41.9 & \multirow[t]{6}{*}{ Education } & \multirow{6}{*}{$\begin{array}{l}\text { Primary } \\
\text { Secondary } \\
\text { High School } \\
\text { Undergraduate } \\
\text { Graduate } \\
\text { No Answer }\end{array}$} & 21 & 8.7 \\
\hline & Male & 139 & 57.7 & & & 15 & 6.2 \\
\hline & No Answer & 1 & 0.4 & & & 74 & 30.7 \\
\hline & & & & & & 127 & 52.7 \\
\hline & & & & & & 2 & 0.8 \\
\hline & & & & & & 2 & 0.8 \\
\hline \multirow[t]{3}{*}{ Status } & Managerial & 52 & 21.6 & \multirow[t]{3}{*}{ Employment } & Full Time & 221 & 91.7 \\
\hline & Non Managerial & 179 & $74 \cdot 3$ & & Part Time & 16 & 6.6 \\
\hline & No Answer & 10 & 4.1 & & No Answer & 4 & 1.7 \\
\hline \multirow[t]{10}{*}{ Department } & Front Office & 43 & 17.8 & \multirow[t]{10}{*}{ Age } & \multirow{10}{*}{$\begin{array}{l}-25 \\
26-35 \\
36+ \\
\text { No Answer }\end{array}$} & 105 & 43.6 \\
\hline & Housekeeping & 28 & 11.6 & & & 72 & 30.9 \\
\hline & Sales \& Marketing & 11 & 4.6 & & & 55 & 22.9 \\
\hline & Food \& Beverage & 53 & 22.0 & & & 9 & $3 \cdot 7$ \\
\hline & Accounting & 19 & $7 \cdot 9$ & & & & \\
\hline & Human Resources & 5 & 2.0 & & & & \\
\hline & Maintenance & 13 & 5.4 & & & & \\
\hline & Spa / Fitness & 14 & 5.8 & & & & \\
\hline & Supporting & 8 & $3 \cdot 3$ & & & & \\
\hline & No Answer & 47 & 19.5 & & & & \\
\hline \multirow{5}{*}{$\begin{array}{l}\text { Experience } \\
\text { (At the } \\
\text { Hotel) }\end{array}$} & $1-3$ & 152 & 63.0 & \multirow{4}{*}{$\begin{array}{l}\text { Total } \\
\text { Hospitality } \\
\text { Experience }\end{array}$} & $1-3$ & 78 & 32.4 \\
\hline & $4-7$ & 45 & 18.6 & & $4-7$ & 74 & 30.7 \\
\hline & $8+$ & 22 & 9.1 & & $8+$ & 84 & $34 \cdot 9$ \\
\hline & No Answer & 22 & 9.1 & & No Answer & 5 & 2.1 \\
\hline & Total & 241 & 100.0 & & Total & 241 & 100.0 \\
\hline
\end{tabular}

\section{Measures}

The study instrument contained multi-item four scales (work engagement, work locus of control, passion, and parasitism) and demographic questions. After each item was translated into Turkish, six tourism and one language scholars confirmed that the Turkish and English statements were consistent. Participants responded to the items using a 7-point scale, ranging from 'always' (1) to 'never' (7). 
The nine-item, short-form Work Engagement Scale, which was adapted from Schaufeli, Taris, and Bakker (2006), has three sub-scales of vigour ( 3 items), dedication ( 3 items), and absorption ( 3 items). In this study, all the items were analysed as one dimension: 'work engagement'. This follows Schaufeli et al. (2006), who recommend using a one-dimensional analysis if the short form is used and the research question does not examine the sub-dimensions (Schaufeli 2003; Schaufeli et al., 2006).

The short-form Work Locus of Control Scale (Spector, 1988) has 8 statements for the two dimensions: internal and external. Our study used the Turkish version developed by Ozgen, Kaygalak, Türksoy, Dilek, and Tütüncü (2014), which demonstrated the validity and reliability of both dimensions.

For passion, six items were adapted from Lafrenière, Vallerand, Carbonneau, Jowett, Paquet, and Bureau (2012), with three items each for harmonious and obsessive passion.

The 14-item parasitism scale was developed by Turksoy (2017), Turksoy and Tutuncu (2020). The scale was proved to be valid and reliable as a measurement tool. The two dimensions are Self-directed (7 items) and Community-directed (7 items). The measures' factor structure had already been tested in previous Turkish studies with CFA and EFA (Ozgen et al. 2014; Ozkalp, \& Meydan 2014; Turksoy, 2017; Turksoy and Tutuncu 2020). Therefore, the analysis started with CFA.

\section{Measurement model assessment}

After identifying the demographics and before testing the hypothesized model, a confirmatory factor analysis (CFA) was performed to test if the model's fit was statistically acceptable. The $t$-values of the observed variables were statistically significant at 0.05 level and greater than 1.96. Factor loadings exceeded 0.50 except for the statement "I get carried away while I am working" in the work engagement scale. That statement was omitted from the analysis (Hair et al., 2014). In this study, the $p$ values were statistically significant. However, according to Hair et al. (2014: 584), if the sample size is less than 250 and the number of observed variables greater than 30 , then significant $p$ values may be expected. The degrees of freedom show the difference between the value in $\chi^{2}$ in the data matrix and the value the researcher wants to obtain. If the ratio of $\chi^{2}$ value's degrees of freedom is below 2 , this indicates perfect fit (Tabachnick \& Fidell, 2001). In this study, it was 1.92, indicating perfect fit. The lowest $t$ value in the model was 6.34. In studies with samples smaller than 250, a RMSEA value of 0.08 indicates that the model fits if CFI values are over 0.92 and SRMR values are lower than 0.90 (Hair et al., 2014: 583-584). Table 2 shows the fit index values. According to Brown (2006), Tabachnick and Fidell (2001), Hu and Bentler (1999), Kline (2005), Schumacker and Lomax (1996), and Hooper, Lambeth, Schapiro, and Whiten (2008) the fit indices values for the measurement model proposed for this study have acceptable values.

Table 2. Goodness of fit index values of measurement model

\begin{tabular}{lllllllllll}
\hline Model & $x^{2}$ & df & $\chi 2 /$ df & RMSEA & NFI & NNFI & CFI & SRMR & GFI & AGFI \\
\hline & 1159.91 & 582 & 1.92 & 0.06 & 0.91 & 0.95 & 0.95 & 0.06 & 0.80 & 0.76
\end{tabular}

Note: $p$-value $<0.000$ 
Table 3. Reliability and confirmatory factor analysis properties

\begin{tabular}{|c|c|c|c|c|c|}
\hline & $\begin{array}{l}\text { Standardized } \\
\text { Values }\end{array}$ & $\begin{array}{ll}t \\
\text { Values }\end{array}$ & AVE & CR & $\begin{array}{l}\text { Cronbach's } \\
\text { alpha }\end{array}$ \\
\hline Employee Engagement (Eng) & & & 0.56 & 0.91 & 0.899 \\
\hline I feel energized at work. & 0.75 & 13.06 & & & \\
\hline At my job I feel strong and vigorous. & 0.77 & 13.74 & & & \\
\hline I am excited / enthusiastic about my job. & 0.87 & 16.56 & & & \\
\hline My job motivates / inspires me. & 0.82 & 15.17 & & & \\
\hline When I get up in the morning, I feel motivated to go to work. & 0.77 & 13.91 & & & \\
\hline I feel happy when I am working hard. & 0.60 & 9.99 & & & \\
\hline I am proud of the work that I do. & 0.74 & 13.00 & & & \\
\hline I am really focused when I am working hard. & 0.65 & 11.10 & & & \\
\hline Internal Work Locus of Control (iwloc) & & & 0.40 & 0.72 & 0.753 \\
\hline $\begin{array}{l}\text { On most jobs, people can pretty much accomplish whatever they } \\
\text { set out to accomplish. }\end{array}$ & 0.60 & 9.18 & & & \\
\hline $\begin{array}{l}\text { If you know what you want out of a job, you can find a job that } \\
\text { gives it to you. }\end{array}$ & 0.83 & 13.13 & & & \\
\hline Promotions are given to employees who perform well on the job. & 0.63 & 9.66 & & & \\
\hline People who perform their jobs well generally get rewarded. & 0.44 & 6.34 & & & \\
\hline External work locus of control (ewloc) & & & 0.47 & 0.78 & 0.818 \\
\hline Promotions are usually a matter of good fortune. & 0.77 & 12.75 & & & \\
\hline It takes a lot of luck to be an outstanding employee on most jobs. & 0.74 & 12.14 & & & \\
\hline Getting the job you want is mostly a matter of luck. & 0.60 & $9 \cdot 36$ & & & \\
\hline $\begin{array}{l}\text { The main difference between people who make a lot of money } \\
\text { and people who make a little money is luck. }\end{array}$ & 0.64 & 1.08 & & & \\
\hline Harmonious passion (harpas) & & & 0.52 & 0.76 & 0.794 \\
\hline My job is in harmony with the other activities in my life. & 0.83 & 14.11 & & & \\
\hline My job allows me to have a variety of experiences. & 0.67 & 1.77 & & & \\
\hline My job is well integrated with my life. & 0.65 & 1.31 & & & \\
\hline Obsessive passion (obspas) & & & 0.42 & 0.68 & 0.706 \\
\hline I have almost an obsessive feeling for my job. & 0.57 & 8.07 & & & \\
\hline If I could, I would only work. & 0.70 & $9 \cdot 97$ & & & \\
\hline I have the impression that my work controls me. & 0.68 & $9 \cdot 77$ & & & \\
\hline Community-directed parasitism (comdpar) & & & 0.44 & 0.84 & 0.872 \\
\hline He/she tries to have close relationship with promoted people. & 0.59 & 9.43 & & & \\
\hline $\begin{array}{l}\text { He/she can spare time for his/her personal affairs during working } \\
\text { hours. }\end{array}$ & 0.67 & 11.29 & & & \\
\hline He/she may direct hard tasks to his/her colleagues. & 0.69 & 11.57 & & & \\
\hline $\mathrm{He} /$ she can take advantage of the frailties of his/her superiors. & 0.77 & 13.48 & & & \\
\hline $\mathrm{He} /$ she can trust his/her close relationships in job applications. & 0.60 & 9.65 & & & \\
\hline $\mathrm{He} /$ she can try all ways to get a promotion & 0.71 & 12.10 & & & \\
\hline He/she can employ acquaintances. & 0.63 & 1.37 & & & \\
\hline Self-directed parasitism (selfdpar) & & & 0.71 & 0.94 & 0.959 \\
\hline He/she tries to shift the blame when criticized. & 0.75 & 13.41 & & & \\
\hline $\begin{array}{l}\text { He/she can appropriate his/her friends' ideas if he/she likes } \\
\text { them. }\end{array}$ & 0.82 & $15 \cdot 35$ & & & \\
\hline $\begin{array}{l}\text { He/she pretends as if he/she is working although the work isn't } \\
\text { done. }\end{array}$ & 0.86 & 16.42 & & & \\
\hline He/she overstates the things he/she does to his/her superiors. & 0.86 & 16.51 & & & \\
\hline He/she can brag about even routine work. & 0.87 & 16.72 & & & \\
\hline $\mathrm{He} /$ she can exaggerate even if the work is very easy. & 0.87 & 16.90 & & & \\
\hline He/she can exaggeratingly describe his/her skills. & 0.88 & 17.29 & & & \\
\hline
\end{tabular}

$\mathrm{AVE}=$ Average Variance Extracted; $\mathrm{CR}=$ Composite Reliability 
Table 3 shows factor loadings in the measurement model, $t$-values, composite reliabilities-CR, Cronbach's alpha, and Average Variance Extracted (AVE) values. AVE values of the four out of seven dimensions failed to reach the required value of 0.5. According to Fornell and Larcker (1981), the construct's convergent validity is adequate if AVE is less than 0.5 while composite reliability is higher than o.6. AVE values for convergent validity are within acceptable limits.

Table 4. Correlation Matrix of the Independent Variables

\begin{tabular}{|c|c|c|c|c|c|c|c|}
\hline & Eng & Iwloc & Ewloc & Harpas & Obspas & $\begin{array}{l}\text { Com-d- } \\
\text { par }\end{array}$ & $\begin{array}{l}\text { Selfd } \\
\text {-par }\end{array}$ \\
\hline Employee Engagement (Eng) & 0.75 & & & & & & \\
\hline Internal Work Locus of Control (Iwloc) & $0.62^{* * *}$ & 0.63 & & & & & \\
\hline External Work Locus of Control (Ewloc) & $-0.29^{* * *}$ & $-0.22^{* *}$ & 0.68 & & & & \\
\hline Harmonious Passion (Harpas) & $0.75^{* * *}$ & $0.59^{* * *}$ & $-0.16^{*}$ & 0.72 & & & \\
\hline Obsessive Passion (Obspas) & $0.26^{* * *}$ & $0.28^{* * *}$ & $0.34^{* * *}$ & $0.42^{* * *}$ & 0.65 & & \\
\hline $\begin{array}{l}\text { Community-Directed } \\
\text { Parasitism (Com-d-par) }\end{array}$ & -0.12 & $-0.20^{* *}$ & $0.51^{* * *}$ & -0.06 & $0.22^{* *}$ & 0.66 & \\
\hline Self-Directed Parasitism (Self-d-par) & $-0.018^{* *}$ & $-0.20^{* *}$ & $-0.39^{* * *}$ & -0.07 & 0.04 & $0.78^{* * *}$ & 0.84 \\
\hline
\end{tabular}

Note: ${ }^{* *} \mathrm{p}<0.001,{ }^{* *} \mathrm{p}<0.01,{ }^{*} \mathrm{p}<0.05$

Table 4 shows that all the variables correlated with each other. The only correlations that were not significant were between community-directed parasitism and engagement, community-directed parasitism and harmonious passion, self-directed parasitism and self-directed parasitism and obsessive passion, harmonious passion. Diagonals values in bold show the square root of AVE while the other values represent the correlation. All discriminant validity values are satisfactory except the correlation of community-directed parasitism and harmonic passion. Square root of AVE of these two factors was slightly lower than the highest correlation with other dimensions, demonstrating limited discriminant validity. Other five dimensions (employee engagement, internal work locus of control, external work locus of control, obsessive passion, and self-directed parasitism) showed good convergent validity and composite reliability, and acceptable discriminant validity. As the study is exploratory study, the structural model and hypothesis were tested next. Nevertheless, it occurs as a limitation.

\section{Testing the Structural Model and Hypotheses}

Each hypothesis was based on a theory with a specific relationship to test. There were three exogenous variables unpredicted by other variables in the model: self-directed and community-directed parasitism, and internal work locus of control. That is, none of the hypotheses explained these variables and there were no paths (uni-directional arrows) linked to these variables in the model. All the remaining variables are considered endogenous. SEM analyses with a model trimming approach was chosen, in which the models were improved step by step by adding further and/or dropping insignificant $(\mathrm{p}>0.05)$ parameters to arrive at a well-fitting model for each age band. The critical value for $t$ value significance at 0.05 is 1.96 (Hair, Ringle, \& Sarstedt, 2011). This first analysis confirmed $H_{1}, H_{2}, H_{3}, H_{7 a}, H_{8 a}, H_{9}, H_{10}$, $H_{13}$, and $H_{17}$ but rejected $H_{4}, H_{5}, H_{6}, H_{7 b}, H_{8 b}$, and $H_{11}$. There was a negative relationship between perceived self-directed parasitism and obsessive passion and a positive correlation between perceived community-directed parasitism and obsessive passion (Model 1). After non-significant paths were removed from the model, the proposed model re-evaluated accordingly with the first analysis. $H_{14}, H_{15}$, $H_{16}$ was rejected because the path from external work of locus of control, obsessive passion to work engagement was not significant. This analysis showed a correlation between perceived communitydirected parasitism and external work locus of control. Furthermore, the relationship between community-directed parasitism and work engagement was fully mediated by external locus of control because the parameter estimates between perceived community- directed parasitism and work 
engagement becomes insignificant $\left(H_{13}\right)$ (Model 2). The fit index values for model 2 (Table 6) met the minimum conditions set by Hair et al. (2014). The new $\chi^{2}$ value and degrees of freedom were 1121.68 and 581 while the $\chi^{2} /$ degree of freedom ratio indicated perfect fit. The $\chi^{2}$ difference test was used to determine the significance of the change. The test indicated a difference of $3.98(p=0.55)$. If there is no significant difference between two models in terms of goodness of fit, the model that tests fewer parameters (i.e. is more parsimonious) should be chosen as it has more degrees of freedom (Werner \& Schermelleh-Engel, 2010; Hair et al, 2014: 587). Therefore, model 2 was accepted.

Table 5. Path coefficients of the structural model

\begin{tabular}{lllll}
\hline & $\boldsymbol{t}$ value & Path Coefficients & $+/-$ \\
\hline Internal work locus of control $\rightarrow$ Work engagement & 2.58 & $0.25^{* *}$ & $H_{1}$ & Supported \\
External work locus of control $\rightarrow$ Work engagement & -2.42 & $-0.15^{*}$ & $H_{2}$ & Supported \\
Harmonious passion $\rightarrow$ Work engagement & 5.93 & $0.58^{* * *}$ & $H_{3}$ & Supported \\
Obsessive passion $\rightarrow$ Work engagement & 0.13 & & $H_{4}$ & Not Supported \\
Community-directed parasitism $\rightarrow$ Work engagement & 1.49 & & $H_{5}$ & Not Supported \\
Self-directed parasitism $\rightarrow$ Work engagement & -1.42 & & $H_{6}$ & Not Supported \\
Internal work locus of control $\rightarrow$ Harmonious passion & 7.84 & $0.63^{* * *}$ & $H_{7 a}$ & Supported \\
Internal work locus of control $\rightarrow$ Obsessive passion & 4.41 & $0.46^{* * *}$ & $H_{7 b}$ & Supported \\
External work locus of control $\rightarrow$ Harmonious passion & -0.08 & & $H_{8 b}$ & Not Supported \\
External work locus of control $\rightarrow$ Obsessive passion & 3.42 & $0.38^{* * *}$ & $H_{8 a}$ & Supported \\
Self-directed parasitism $\rightarrow$ Obsessive passion & -2.02 & $-0.24 *$ & $H_{9}$ & Supported \\
Community-directed parasitism $\rightarrow$ Obsessive passion & 2.06 & $0.28^{*}$ & $H_{10}$ & Supported \\
Self-directed parasitism $\rightarrow$ External work locus of control & -0.24 & & $H_{11}$ & Not Supported \\
Community-directed parasitism $\rightarrow$ External work locus of & 4.01 & $0.51 * * *$ & $H_{12}$ & Supported \\
control & & & &
\end{tabular}

Note: ${ }^{* *} \mathrm{p}<0.001,{ }^{* *} \mathrm{p}<0.01,{ }^{*} \mathrm{p}<0.05$

To test the mediation effect of harmonious passion on work engagement, the proposed model was reestimated by constraining the direct effect of harmonious passion on work engagement, and the new values were analysed. If this path resulted in better fit indices and caused more significant change, then model 3 would be accepted. However, there was no significant change. The new $\chi_{2}$ value and degrees of freedom for model 3 were 1159.91 and 582 respectively. The $\chi^{2} /$ degree of freedom ratio indicated perfect fit. The $\chi_{2}$ difference test result was $38.23(\mathrm{p}=0.001)$, indicating that the difference caused a significant disruption at .05 level. Since the difference of the fit indices between two models was significant, it was more appropriate to keep the path suitable to the fit indices in the model. In this case, Model 2 was accepted (Hair et al., 2014: 587). According to the model, internal work locus of control predicted harmonious passion $\beta=0.63 \mathrm{p}<0.001)$ and harmonious passion predicted engagement $(\beta=$ $0.58 \mathrm{p}<0.001)$. The results show that although the indirect effect of internal work locus of control on work engagement through mediation of harmonious passion was $0.36(\beta=0.63 \times 0.58=0.36 \mathrm{p}<0.001)$, the direct effect of internal work locus of control on work engagement was $0.25(\mathrm{p}<0.01)$. The indirect effect is stronger than direct effect. $H_{17}$ was accepted. Regarding the structural model's explanatory power for work engagement, internal locus of control was 0.25; harmonious passion was 0.58; while community-directed parasitism via full mediation of external locus of control was -0.15.

Table 6. Fit Index Values of Models 1-3

\begin{tabular}{llllllllllll}
\hline Model & $\chi^{2}$ & $\mathrm{df}$ & $\chi^{2} / \mathrm{df}$ & RMSEA & NFI & NNFI & CFI & SRMR & GFI & AGFI & $\chi^{2}$ difference \\
\hline Model 1 & 1117.70 & 576 & 1.94 & 0.06 & 0.91 & 0.95 & 0.95 & 0.06 & 0.79 & 0.76 & \\
Model 2 & 1121.68 & 581 & 1.93 & 0.06 & 0.91 & 0.95 & 0.95 & 0.06 & 0.79 & 0.76 & $3.98(p=0.55)$ \\
Model 3 & 1159.91 & 582 & 1.99 & 0.06 & 0.91 & 0.95 & 0.95 & 0.07 & 0.79 & 0.76 & $38.23(p=0.001)$ \\
\hline
\end{tabular}

Note: $p$-value $<0.05$ 


\section{Discussion and Conclusion}

This study was conducted within the framework of the JD-R model to determine the effects on work engagement of the relationships between perceived self- and community-directed parasitism, internal and external work locus of control, harmonious and obsessive passion. The structural model developed based on prior theory was tested by structural equation modelling. The scales used were work engagement, work locus of control, passion, and parasitism. The validity and the reliability of the scales were confirmed by confirmatory factor analysis and structural equation modelling was used to test the models. $H_{1}, H_{2}, H_{3}, H_{7 a}, H_{8 a}, H_{9}, H_{10}, H_{13}$, and $H_{17}$ were supported but $H_{4}, H_{5}, H_{6}, H_{7 b}, H_{8 b}, H_{11}, H_{14}, H_{15}$, and $H_{16}$ were rejected. The relationship between community-directed parasitism and work engagement was fully mediated by external locus of control. The relationship between internal work locus of control and work engagement was partially mediated by harmonious passion.

\section{Theoretical Implications}

In the literature, parasitic relationships at work are generally explained in terms of free riding, selfishness, and prioritizing individual interests over collective interests. However, there has been no direct study in relation to parasitism, although it has been addressed indirectly within evolutionary psychology. This study used a recently developed scale for measuring parasitic relationships, which can help to develop clearer theoretical definitions and conceptual models. Individuals who form parasitic relationships prioritize achieving a rational goal with the least effort. Some argue that self-seeking individuals may not pose a problem for society because the pursuit of individual interests may help preserve collective interests. However, within work organizations, parasitic behaviours like favouritism, shifting responsibility onto others, and pretending to work can be difficult for other employees to bear. Because such behaviour can reduce motivation and increase physiological workload, it is an important problem for organizations to identify, given the need for greater efficiency nowadays. This study contributes to the literature by identifying parasitic relationships and their effects on work engagement along with other variables in a theoretically grounded way.

Within the JD-R model, workers identify parasitic attitudes, behaviours, and relationships as job demands, and a negative aspect of an organization, which in turn creates physical and psychological costs. Consequently, as parasitic relations increase, employees need more job resources.

Employees with internal work locus of control and harmonious passion may manage parasitic relations better, achieve work targets, and start a process that may motivate them to improve their performance. Individuals with internal work locus of control have stronger job resources, which can offset the negative effects of job demands (Jha \& Nair, 2008), while internal locus of control, social support, and work autonomy mitigate the negative impact of stressors on well-being (Daniels \& Guppy, 1994). Internal work locus of control increases work engagement. Conversely, people with external work locus of control are less able to manage the pressures and ambiguities that challenge them at work (Rahim \& Psenicka, 1996) and may therefore experience burnout syndrome (De Hoogh \& Hartog, 2009). Similarly, there was a negative correlation between external work locus of control and work engagement in the present study.

Regarding passion, harmonious passion increased work engagement in our study, which supports Trepanier et al. (2014). The feelings anger, frustration, and conflicts of employees experiencing obsessive passion endanger the employee motivation and energy. Employees who feel forced to work intensively may lose revival. Similarly, we found no correlation between obsessive passion and work engagement. It supports previous studies based on the JD-R model which have shown that obsessive passion is 
associated with health impairment rather than work engagement through emotional exhaustion and depersonalization (Fernet et al., 2014).

On the other hand, we found no correlation between perceived parasitic relations and work engagement. Therefore, this study did not support the idea that parasitic relations weaken employees' work engagement by imposing additional psychological and physiological burdens on employees. Engagement refers to the relationship between the employee and the job and work engagement focuses on the employee's feelings about the job. Engaged employees experience physical, cognitive and emotional fulfilment of job roles. Engaged employees have strong positive feelings with motivation. Research revealed that engaged employees are energetic and able to effectively manage the events that affect their lives (Bakker, 2009). Therefore; the results show that they manage the parasitic relations in their lives easily.

The positive correlation between internal work locus of control and harmonious passion, and the negative correlation between obsessive passion was partially supported. Internal work locus of control increased both harmonious $(r=0.63)$ and obsessive passion $(r=0.42)$. Employees with Internal locus of control have high career expectations. They are interested in their work environment and are willing to have control. They are usually successful employees with higher performance. Therefore; it is possible to be passionate at work (Harmonious passion). If the feeling of success becomes an uncontrollable obsessive desire, obsessive passion may occur towards work. In contrast, external work locus of control increased obsessive passion $(r=0.37)$ but not harmonious passion. It can be explained through the feeling of external pressure and stress by the employees. If the employee usually does things he has to do with external pressure or has a controlled personality, the controlled internalization process of the job leads to obsessive passion (Vallerand et al., 2014: 97). Whereas these relationships were strong in the present study, Zigarmi et al. (2018) found only a moderate correlation between internal work locus of control and harmonious passion (0.22), and a weak correlation between external work locus of control and obsessive passion $(r=0.13)$ in their model explaining the relationship between internal and external locus of control, motivation, work passion, and work intentions.

Regarding mediation effects, we found that the relationship between community-directed parasitism and work engagement was fully mediated by external locus of control. The perceived communitydirected parasitism caused employees to have external work locus of control which in turn although weakly, affected work engagement negatively. Employees with external locus of control believe that outputs like promotion and success in the workplace are not under their control but others' (e.g. auditors, managers, the organization, luck, or fate). Thus, perceived parasitic relations may make them believe that relationships in the workplace are controlled by factors outside of their control. They lose their motivation and energy towards job.

The analysis also showed that harmonious passion partially mediated the relationship between internal locus of control and work engagement. Internal locus of control leads employees to develop strong harmonious passion, which in turn increases their work engagement. This supports that autonomous employees with internal work locus of control will show harmonious passion and engage in the job voluntarily without being affected by other compelling conditions. Another result of the mediation analysis was the moderate direct positive effect of internal work locus of control on work engagement $(r=0.25)$. Employees with internal work locus of control have some personality resources such as being effective in their work environment, developing knowledge-gathering behaviours (Spector, 1982) which can lead to engagement. Finally, both perceived self- and community-directed parasitism were correlated with obsessive passion. In obsessive passion, it is not the individual who controls the passion, 
obsessive passion captures the work itself, and this situation becomes an inner pressure linked with one's identity at work. This may force them to work harder to achieve success, and internalize work in a controlled way.

\section{Practical Implications}

Nowadays, businesses are challenged by increasingly competitive conditions. In response, they are adopting practices like reviewing business processes, rethinking management structures, and decreasing employee numbers. However, they could also improve business performance and efficiency by first selecting the right employees and then increasing their work engagement. Businesses must work with engaged, loyal, and high-performing employees.

As the hospitality and tourism industry is labour intensive, with simultaneous production and consumption processes, the human factor is crucial for service quality and customer satisfaction. Since engaged employees focus on and allocate all their energy to their work better due to having positive emotions and ways of thinking, they may create their own personal and job resources. They may in turn improve team performance by influencing colleagues.

Engaged employees are energetic individuals who can manage their lives (Bakker, 2009). The positive attitude and degree of activity of engaged employees provides its own positive feedback through appreciation, recognition, and success. Although engaged employees feel tired after a long workday, they define this fatigue as a pleasant feeling due to their achievements. Moreover, engaged employees are positively affected by other elements outside of work. Contrary to workaholics, they state that the driving force behind them is the sentiment of work being fun rather than an irresistible inner instinct to work (Gorgievski, Bakker, \& Schaufeli, 2010). Seasonality in tourism and flexible working conditions create challenging job demands, so employees may easily experience burnout. To prevent this, job and personal resources are required, so it is important for employees of hospitality facilities to have internal work locus of control and harmonious passion. Job and personal resources lead to work engagement, which then improves performance.

This study showed that internal work locus of control and harmonious passion increase work engagement while harmonious passion partially mediates the relationship between internal locus of control and work engagement. Organizations should therefore adopt approaches that encourage employees to develop internal locus of control. When employees think that their own control helps them to achieve goals, then they will become more innovative, creative, and productive in the workplace. Conversely, repeated failures in control can make employees depressed, and attribute their failures to their supervisors, families, low wages, boss, luck, or fate. They may then become more likely to quit their jobs (Forte, 2005). To prevent such undesirable workplace outcomes, management should create an environment that fosters job satisfaction, self-respect, and opportunities for employees to express their desire for a better quality of life and increase inner motivation (Karimi \& Alipour, 2011). Hotel managers should review their management approaches so that they can help to strengthen employees' feelings of self-control in their jobs and work environment through business development, enrichment, and by delegating decision-making and authority (Salami, Ojokuku, \& Ilesanmi, 2010). Such programs may increase hotel employees' motivation and enable them to better manage job demands like flexible and long working hours. This could then improve their performance and work engagement. Finally, higher wages and promotion opportunities can help employees to develop internal work locus of control (Karimi \& Alipour, 2011). 
Organizational characteristics also influence the type of passion that employees develop. If a business fosters collaboration, loyalty, development, and communication, its employees tend to develop harmonious passion whereas employees of target-oriented businesses that prioritize competition, profitability, and achievement encourage obsessive passion (Vallerand et al., 2014). Thus, hospitality businesses could adopt different approaches to allow employees to realize their own strengths to improve their performance. Relationships based on excessive control and correction should be avoided. Instead, hospitality businesses should promote autonomy, value employee behaviours and thoughts, and support collaboration, loyalty, development, and communication. Managers should avoid creating a work environment dominated by competition, achievement, targets, and profitability.

To make it easier to implement these organizational and managerial practices, companies should hire employees who already have internal work locus of control and harmonious passion. Recruitment should identify applicants with emotional intelligence, empathy, and an ability to develop independent behaviour. Employees with high emotional intelligence develop more empathy, are aware of their power of influence, and can behave more independently. These characteristics in turn encourage harmonious passion (Houlfort \& Rinfret, 2010). To increase employee work engagement, hospitality businesses should review the annual business plans of their human resources departments, and establish training centres to provide training to better meet the specific needs of employees. Senior executives may conduct meetings with all employees while touring the enterprise to communicate better at the individual level. In addition, updating information and communication systems, and determining business processes and user requirements may help an enterprise operate better. Finally, Schaufeli (2017) found that adopting such increased the job satisfaction and work engagement of hotel employees by $2 \%$.

This study also revealed that hospitality business employees who perceived community-directed parasitic relations had lower work engagement and stronger external work locus of control. This may weaken the perception of a fair working environment based on merit and promote the idea that factors like close relations, favouritism, and string-pulling affect success and promotion, no matter how hard the individual works. Parasitic relations can be prevented through fair managerial behaviours, clear definition of the responsibilities of managers and employees, and objective criteria for performance monitoring and feedback. If a company has more engaged employees, who can improve business performance, then it becomes easier to reduce workforce turnover, which is a significant challenge for hospitality businesses.

\section{Limitations and future research}

This study focused on Cesme, in Izmir province in Turkey, where coastal hotels are mostly seasonal businesses. Future studies could usefully compare the findings to city (central) hotels and resort hotels using a larger sample. This study evaluated work engagement as one dimension due to using the nineitem short form of the scale. Future studies could therefore use the long form to examine the relationships between the sub-dimensions. This study was based on the motivation processes of the JD$\mathrm{R}$ model. Future could investigate the deterioration in health and relationships due to burnout. Two constructs in the study demonstrated limited discriminant validity although other five constructs showed good convergent validity and composite reliability, and acceptable discriminant validity. It occurs as a limitation.

\section{References}

Anitha, J. (2014). Determinants of employee engagement and their impact on employee performance. International Journal of Productivity and Performance Management, 63(3), 308-323. 
Arakawa, D., \& Greenberg, M. (2007). Optimistic managers and the influence on productivity and employee engagement in a technology organization: Implications for coaching psychologists. International Coaching Psychology Review, 2(1), 78-89.

Attridge, M. (2009). Measuring and Managing Employee Work Engagement: A Review of the Research and Business Literature. Journal of Workplace Behavioral Health, 10(24), 383-398.

Atalay, M., \& Acar, A. (2016). An Investigation of the Subservience Behaviour in Organizations from the Perspective of Leader-Member Interaction. 24. The Congress Book of National Congress of Management and Organisation. 29-31 May 2016. Istanbul, 330-334.

Bakker, A. B., \& Demerouti, E. (2008). Towards a model of work engagement. Career Development International, 13(3), 209-223.

Bakker, A.B., Van Emmerik, H., \& M.C. Euwema (2006). Crossover of burnout and engagement in work teams. Work and Occupations, 33, 464-489

Bakker, A.B. (2009). Building Engagement in Workplace. Oxon: Routledge.

Bakker, A.B., \& Bal, P. M. (2010). Weekly Work Engagement and Performance: A Study Among Starting Teachers. Journal of Occupational and Organizational Psychology, 83, 189-206.

Bakker, A.B., Demerouti, E., \& Xanthopoulou, D. (2012). How do engaged employees stay engaged? Ciencia \& Trabajo, 14 (special issue), 15-21.

Bakker, A.B., Demerouti, E., \& Sanz-Vergel, A.I. (2014). Burnout and work engagement: the JD-R approach. Annual Review of Organizational Psychology and Organizational Behavior, 1(1), 389-411.

Brown, T. A. (2006). Confirmatory factor analysis for applied research. New York: Guilford Press.

Daniels, K., \& Guppy, A. (1994). Occupational stress, social support, job control, and psychological wellbeing. Human Relations. 47(12), 1523-1544.

De Hoogh, A. B., \& Hartog, D. (2009). Neuroticism and locus of control as moderators of the relationships of charismatic and autocratic leadership with burnout. Journal of Applied Psychology. 94(4), 1058-1067.

Demerouti E., Bakker A. B., De Jonge J., \& Janssen, P. P. M. (2001). Burnout and engagement at work as a function of demands and control. Scandinavian Journal of Work, Environment $\mathcal{E}$ Health, 27, 279288.

Etzion, D., \& Westman, M. (1994). Social support and sense of control as moderators of the stressburnout relationship in military careers. Journal of Social Behavior and Personality, 9, 639-656.

Felps, W., Mitchell, T.R., \& Byington, E. (2006). How, when, and why bad apples spoil the barrel: Negative group members and dysfunctional groups. Research in Organizational Behavior, 27, 175222

Fernet, C., Lavigne, G.L, Vallerand, R.J., \& Austin, S. (2014). Fired up with passion: Investigating how job autonomy and passion predict burnout at career start in teachers work and stress. An International Journal of Work, Health E Organisations, 28(3), 270-288.

Forte, A. (2005). Locus of control and the moral reasoning of managers. Journal of Business Ethics. 58(1), 65-77.

Gorgievski, M.J., Bakker, A.B., \& Schaufeli, W.B. (2010). Work engagement and workaholism: comparing the self-employed and salaried employees. The Journal of Positive Psychology. 5(1), 83-96.

Hair, J.H., Black, B., Babin, \& B., Anderson, R.E., (2014). Multivariate Data Analysis (7th ed.). Essex: Pearson.

Hair, J. F., Ringle, C. M., \& Sarstedt, M. (2011). PLS-SEM: indeed a silver bullet. Journal of Marketing Theory and Practice, 19(2), 139-151

Hicks H. G., \& Gullett C. R. (1981). Organizations: Theory and Behaviour, (ed. B. Baykal). Istanbul.

Hopper, L. M., Lambeth, S. P., Schapiro, S. J., \& Whiten, A. (2008). Observational learning in chimpanzees and children studied through 'ghost' conditions. Proceedings of the Royal Societies, $835-884$. 
Houlfort, N., \& Rinfret, N. (2010). Fovoriser la satisfaction au travail des direkcteurs generaus du reseau de la sante et des service sociaux. in D. B. Raveleau \& F. B. Hassel (ed). Management humain des organisations: grandeurs et miseres de la fonctin de dirigeant. Paris: Editions L'Harmattan.

Houlfort, N., Vallerand, R. J., Lavigne, G. L., Koesnter, R., Forest, J., Benabou, C., \& Crevier-Brauod, L. (2011). On the Role of Passion for Work in Psychological Well-Being. Manuscript Submitted for Publication.

Houlfort, N., Fernet, C., Vallerand, R. J., Laframboise, A., Guay, F., \& Koestner, R. (2015). The role of passion for work and need satisfaction in psychological adjustment to retirement. Journal of Vocational Behavior, 88, 84-94.

Hu, L., \& Bentler, P.M. (1999). Cutoff criteria for fit indexes in covariance structure analysis: conventional criteria versus new alternatives. Structural Equation Modeling. 6, 1-55.

Jha, S. S., \& Nair, S. K. (2008). Influence of locus of control, job characteristics and superior-subordinate relationship on psychological empowerment. Journal of Management Research. 8(3), 147-161.

Jiang, K., Lepak, D. P., Hu, J., \& Baer, J. C. (2012). How does human resource management influence organizational outcomes? a meta-analytic investigation of mediating mechanisms. Academy of Management Journal, 55(6), 1264-1294.

Kang, H.J. (2014). A Model of Hospitality Employee Engagement. (Unpublished Doctoral Dissertation). Las Vegas: University of Nevada.

Karatepe, O.M. (2012). Job Resources, Work Engagement, and Hotel Employee Outcomes: A TimeLagged Analysis. Ekonomska Istrazivanja-Economic Research, 25(4), 1127-1140.

Karatepe, O.M., \& Olugbade, O.A. (2016). The Mediating Role of Work Engagement in The Relationship between High-Performance Work Practices and Job Outcomes of Employees in Nigeria. International Journal of Contemporary Hospitality Management, 28(10), 2350-2371. https://doi.org/10.1108/IJCHM-03-2015-0145

Karimi, R., \& Alipour, F. (2011). Reduce job stress in organization: Role of locus of control. International Journal of Business and Social Science, 2(18), 232-236.

Kline, R.B. (2005). Principles and Practice of Structural Equation Modeling (2nd Edition ed.). New York: The Guilford Press.

Koeske, G.E., \& Kirk, S.A. (1995). Direct and indirect effects of internal locus of control among mental health professionals. Journal of Social Science Research. 20, 1-28.

Kozak, M., Kozak, M.A., \& Kozak, N. (2015). Genel Turizm: İlkeler - Kavramlar. Ankara: Detay Yayıncılık.

Lafrenie`re, M.A.K., Vallerand, R. J., Carbonneau, N., Jowett, S., Paquet, Y., \& Bureau, J. S. (2012). A short form of the passion scale: evaluation of factorial validity and invariance across demographic variables and activity categories. Manuscript submitted for publication.

Lee, J. (2012). Antecedents and consequences of employee engagement: empirical study of hotel employees and managers. (Unpublished Doctoral Dissertation). Kansas: Kansas State University.

Fornell C., \& Larcker, D.F. (1981). Evaluating structural equation models with unobservable variables and measurement error. Journal of Marketing Research, 18 (1), 39-50

Mäkikangas, A., \& Kinnunen, U. (2003). Psychosocial stressors and well-being: self-esteem and optimism as moderators in a one-year longitudinal sample. Personality and Individual Difference. 35, 537-557.

Manzano, G.G., Montanes, P., \& Megias, J.L. (2017). Perception of economic crisis among Spanish nursing students: Its relation to burnout and engagement. Nurse Education Today, 52, 116-120.

Merriam Webster Dictionary (2016). https://www.merriam-webster.com/dictionary/parasites

Ozbilgin M.F., Kucukaltan, B., \& Acar A. (2019). Sycophancy as a Factor that Corrodes Merit in Academic Life. Business \& Management Studies: An International Journal, 7(5), 2828-2850. doi: http://dx.doi.org/10.15295/bmij.v7i5.1361 
Ozgen, H. K., Kaygalak, S., Turksoy, S.S., Dilek, S.E., \& Tutuncu, O. (2014). The Analysis of Work Locus of Control at Hospitality. VII. The Research Congress of Tourism Graduate Students (p. 200-211). 4-5 April. Aydın.

Ozkalp, E., \& Meydan B. (2014). The Validty and Reliability Analysis of the Work Engagement Scale of Schaufeli ve Bakker in Turkish, Organizational Behaviour Congress Book. (p. 869-882). Meliksah University, Kayseri. 7-8 November.

Rahim, M. A., \& Psenicka, C. (1996). A structural equations model of stress, locus of control, social support, psychiatric symptoms, and propensity to leave a job. The Journal of Social Psychology, 136(1), 69-84.

Rich, B. L., Lepıne, J. A., \& Crawford, E. R. (2010). Job engagement: antecedents and effects on job performance. Academy of Management Journal, 53, 617-635.

Salami, A., Ojokuku, R., \& Ilesanmi, O. (2010). Impact of Job Stress on Managers' Performance. European Journal of Scientific Research. 45(2), 249-26.

Schaufeli, W.B. (2003). Past Performance and Future Perspectives of Burnout Research. South African Journal of Industrial Psychology, 29, 1-15.

Schaufeli, W. B., Salanova, M., Gonzalez-Roma, V., \& Bakker, A. B. (2002). The measurement of engagement and burnout: a two sample confirmatory factor analytic approach. Journal of Happiness Studies, 3, 71-92

Schaufeli, W.B. (2013). What is engagement? In C. Truss, K. Alfes, R. Delbridge, A. Shantz, \& E. Soane (Eds.). Employee Engagement in Theory and Practice. London: Routledge.

Schaufeli, W.B. (2017). Applying the Job Demands-Resources model: A 'how to' guide to measuring and tackling work engagement and burnout. Organizational Dynamics, 46, 120-132.

Schaufeli, W.B., \& Taris T.W. (2014). A critical review of the job demands-resources model: implications for improving bridging occupational. Organizational and Public Health: A Transdisciplinary Approach. Springer Science +Business Media Dordrecht.

Schaufeli, W.B., \& A.B. Bakker (2004). Job Demands, Job Resources and Their Relationship with Burnout and Engagement: a Multi-Sample Study. Journal of Organizational Behavior, 25, 293-315

Schumacker, R. E., \& Lomax, R. G. (1996). A Beginner's Guide to Structural Equation Modeling. Mahwah, NJ: Lawrence Erlbaum Associates.

Schaufeli, W.B., Taris, T.W., \& Bakker, A. (2006). Dr. Jekyll and Mr. Hyde: On the differences between work engagement and workaholism. in Research companion to working time and work addiction, Edited by: Burke, R., 193-217. Northhampton, MA: Edward Elgar.

Spector, P. E. (1988). Development of the work locus of control scale. Journal of Occupational Psychology. 61(4), 335-34.

Tabachnick B.G., \& Fidel, L.S. (2001). Using Multivariate Statistics. (4th ed). MA. Allyn \& Bacon.

Tre'panier, G., Fernet, S.C., Austin, S., Forest, J., \& Vallerand, R.J. (2014). Linking job demands and resources to burnout and work engagement: Does passion underlie these differential relationships? Motiv Emot. 38, 353-366.

Turksoy, S.S (2017). Analysis of the Relationship among Work Engagement, Work Locus of Control, Passion and Parasites in Hotels, (Unpublished Doctoral Dissertation). Dokuz Eylul University/Social Sciences Institute, İzmir.

Turksoy, S., \& Tutuncu O. (2019). Organizational Parasites:Are Our Efforts Equal? Naman Sharma(Ed.) Analyzing Workplace Deviance in Modern Organizations (p. 203-227). ABD: IGI Global. DOI: 1.4018/978-1-5225-9996-8.cho11

Werner, C., \& Schermelleh-Engel, K. (2010). Deciding Between Competing Models: Chi-Square Difference Tests. Erişim: https://www.researchgate.net/publication/241278052_Deciding_Between_ Competing_Models_Chi-Square_Difference_Tests 
Vallerand, R. J. (2010). On Passion for life activities: the dualistic model of passion. in M. P. Zanna (ed). Advances in Experimental Social Psychology, 42, 97-193.

Vallerand, R. J., Houlfort N., \& Forest, J. (2014). Passion for work: determinants and outcomes. The Oxford Handbook of Work Engagement (pp. 85-105). Editor Marylene Gagne. Oxford: Oxford University Press.

Xanthopoulou, D., Bakker, A.B., Demerouti, E., \& Schaufeli, W.B. (2009). Reciprocal relationships between job resources, personal resources, and work engagement. Journal of Vocational Behavior, 74, 235-244.

Zigarmi, D., Galloway, F. J., \& Roberts, T. P. (2018). Work locus of control, motivational regulation, employee work passion, and work intentions: An empirical investigation of an appraisal model. Journal of Happiness Studies: An Interdisciplinary Forum on Subjective Well-Being, 19(1), 231256.

Received: 25/04/2020

Accepted: 28/o1/2021

Coordinating editor: Berta Ferrer-Rosell 